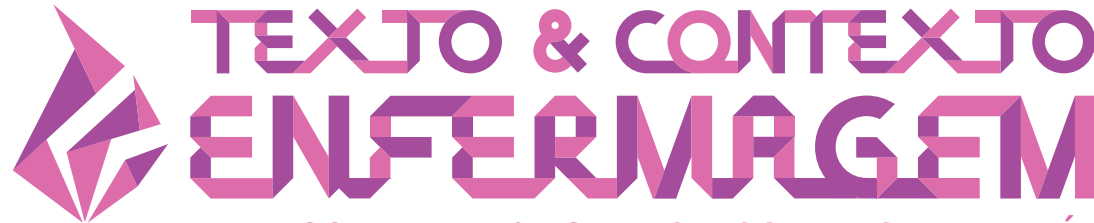

TEXT \& CONTEXT NURSING TEXTO \& CONTEXTO ENFERMERÍA

\section{INCIDENCE OF SKIN INJURIES, RISK \\ AND CLINICAL CHARACTERISTICS OF CRITICAL PATIENTS}

\author{
Dandara Soares Monteiro' ${ }^{1}$ (i) \\ Eline Lima Borges ${ }^{1}$ \\ Josimare Aparecida Otoni Spira' ${ }^{1}$ (D) \\ Taysa de Fátima Garcia ${ }^{1}$ (D) \\ Selme Silqueira de Matos $^{1}$ (D)
}

${ }^{1}$ Universidade Federal de Minas Gerais, Escola de Enfermagem. Belo Horizonte, Minas Gerais, Brasil.

\begin{abstract}
Objective: to analyze the incidence of skin injuries, risk and clinical characteristics of critically ill patients. Method: a retrospective cohort study performed in the intensive care center with a sample of 125 patients whose outcome was skin injury.

Results: the overall injury incidence was $28 \%(n=35)$, with $36.3 \%(n=8)$ being dermatitis associated with urinary and fecal incontinence, $19.2 \%(n=24)$ pressure injury, $7.2 \%(n=9)$ skin tears, and $0.8 \%(n=1)$ medicaladhesive-related skin injury. The appearance time of the injuries varied from 1 to 44 days. The average number of injuries per patient was 1.7. Factors such as enteral nutrition $(p<0.001)$, mechanical ventilation $(p=0.001)$, fecal incontinence $(p=0.049)$, diaper use with a delayed urinary catheter or urinary diversion $(p=0.004)$ were associated with injury onset.

Conclusions: incontinence-associated dermatitis and pressure injury had a higher incidence in critically ill patients. Patients who developed pressure injuries were at higher risk.
\end{abstract}

DESCRIPTORS: Wounds and injuries. Incidence. Critical care. Nursing care. Safety management. 


\section{INCIDÊNCIA DE LESÕES DE PELE, RISCO E CARACTERÍSTICAS CLÍNICAS DE PACIENTES CRÍTICOS}

\section{RESUMO}

Objetivo: analisar a incidência de lesões de pele, risco e características clínicas dos pacientes críticos. Método: coorte retrospectiva realizada no centro de tratamento intensivo com amostra de 125 pacientes cujo desfecho foi ocorrência de lesão de pele.

Resultados: a incidência global de lesão foi de $28 \%(n=35)$, sendo $36,3 \%(n=8)$ dermatite associada à incontinência urinária e fecal,19,2\% ( $n=24)$ lesão por pressão,7,2\% (n=9) lesão por fricção e $0,8 \%(n=1)$ lesão relacionada a adesivos médicos. O tempo para surgimento das lesões variou de 1 a 44 dias. A média de lesões por paciente foi de 1,7. Fatores como nutrição enteral $(p<0,001)$, ventilação mecânica $(p=0,001)$, incontinência fecal $(p=0,049)$, utilização de fralda com cateter vesical de demora ou derivação urinária $(p=0,004)$ tiveram associação com o surgimento de lesão.

Conclusões: dermatite associada à incontinência e lesão por pressão tiveram maior incidência nos pacientes críticos. Pacientes que desenvolveram lesão por pressão apresentaram risco mais elevado.

DESCRITORES: Ferimentos e lesões. Incidência. Cuidados críticos. Cuidados de enfermagem. Gestão da segurança.

\section{INCIDENCIA DE LESIONES DE PIEL, RIESGO Y CARACTERÍSTICAS CLÍNICAS DE PACIENTES CRÍTICOS}

\section{RESUMEN}

Objetivo: analizar la incidencia de lesiones de piel, riesgo y características clínicas de pacientes críticos.

Método: cohorte retrospectivo realizado en centro de tratamiento intensivo sobre muestra de 125 pacientes con presencia de lesiones de piel.

Resultados: la incidencia global de lesión fue del $28 \%(n=35)$, siendo $36,3 \%(n=8)$ dermatitis asociada a incontinencia urinaria y fecal,19,2\% $(n=24)$ lesión por presión,7,2\% $(n=9)$ lesión por fricción, y $0,8 \%(n=1)$ lesión por adhesivos médicos. El tiempo de surgimiento para las lesiones varió entre 1 y 44 días. El promedio de lesiones por paciente fue de 1,7 . Factores como nutrición enteral $(p<0,001)$, ventilación mecánica $(p=0,001)$, incontinencia fecal $(p=0,049)$ uso de pañales con catéter vesical de demora o derivación urinaria $(p=0,004)$ tuvieron asociación con el surgimiento de lesión.

Conclusiones: dermatitis asociada a incontinencia y lesión por presión tuvieron mayor incidencia en pacientes críticos. Los pacientes que desarrollaron lesión por presión expresaron mayor riesgo.

DESCRIPTORES: Heridas y Traumatismos; Incidencia; Cuidados Críticos; Atención de Enfermería; Administración de la Seguridad. 


\section{INTRODUCTION}

The skin is considered the largest organ in the human body in terms of surface area and weight. It covers the whole organism and forms a protective barrier against external aggressions ${ }^{1}$. However, changes in the microclimate (humidity and temperature) or tissue perfusion, nutrition and the presence of comorbidities ${ }^{2}$ can compromise tissue tolerance, allowing the appearance of injuries such as incontinence-associated dermatitis, skin tears, medical-adhesive-related skin injury, or pressure injury.

The occurrence of injuries of certain etiologies in health units is considered an avoidable event and their prevention is ensured by Brazilian and international guidelines on patient safety. The Brazilian Ministry of Health instituted the National Patient Safety Program in 2013, in which one of the objectives is to reduce the risk of unnecessary damage associated with healthcare, which includes the prevention of injuries, and most importantly pressure injuries ${ }^{3}$.

The risk of injury in the intensive care unit (ICU) is greater due to the critical conditions of the patient ${ }^{4}$, such as hemodynamic instability, the use of medications, decreased or restricted mobility and bed positions, and invasive procedures. The presence of an injury directly impacts an increase in treatment costs, length of stay and risk of complications, representing a challenge for the institutions and professionals involved in critical nursing care. In addition, it causes discomfort and pain to the patient, affecting their well-being and quality of life, and above all leaves a scar on the body.

The incidence of these injuries varies according to the characteristics, care level and health institutions in different countries. Incontinence- associated dermatitis varies from $20.0 \%$ in Brazil $^{5}$ to $73.0 \%$ in the United States of America ${ }^{6}$. A cohort covering the United States and Canada demonstrated an $8.4 \%$ incidence of incontinence-associated dermatitis in institutionalized patients in long-term care units, and of $19.0 \%$ in intensive care units ${ }^{7}$. Although little studied, skin tears can vary from $3.3 \%$ to $22.0 \%$ in the hospital context ${ }^{8}$, while medical-adhesive-related skin injuries can range from $7.1 \%$ in the hospital context to $15.5 \%$ in long-stay institutions ${ }^{9}$.

Pressure injuries in bony prominences have been reported in about $1.8 \%$ in Turkey and $16.6 \%$ to $18.5 \%$ in Norway ${ }^{10-11}$. In the period from 2014 to 2019 , a total of 60,762 of 330,536 cases of healthcare incidents in Brazil corresponded to the occurrence of pressure injuries, in which:18,757 were classified as stage $1 ; 32,818$ as stage $2 ; 6,058$ as $3 ; 1,868$ as stage 4 ; and 1,261 were not identified ${ }^{12}$.

In order to assess nursing care quality, it is essential to adopt indicators related to the topic of injury prevention, for example injury incidence and prevention measures which are actually implemented. An analysis of the indicators provides results which support reviewing protocols, the nursing process and signal a need for team training ${ }^{13}$.

Adverse events, especially injuries, represent a major challenge for health institutions and professionals. In addition to the economic impact, they demand an increase in care and therapeutic care, such as the use of special coverings for treatment and specialized professionals for this care ${ }^{13}$.

Preventing injuries in the ICU should be part of the nurse's daily activities, considering that this professional provides direct care to the patient, prepares the care plan and performs safety management with the team and family, which includes recognizing risk factors, adopting preventive measures and early identification of this event.

Many studies related to the occurrence of pressure injuries in bony prominences have been carried out in Brazil ${ }^{2,4,10-11}$. However, publication of studies which together contemplate the occurrence of skin injuries of different etiologies, such as incontinence-associated dermatitis with, skin tears, medical-adhesive-related skin injuries, as well as pressure injuries in bony prominences and medical device-related pressure injuries remains incipient. Due to the magnitude of nursing care for critical patients and the impact of the occurrence of these injuries on patients and health institutions, this study aimed to analyze the incidence of skin injuries, risk and clinical characteristics of critical patients. 


\section{METHOD}

This is a retrospective cohort study which evaluated the outcome of the appearance of one or more types of skin injuries (pressure injuries, skin tears, incontinence-associated dermatitis and medical-adhesive-related skin injuries). The study was carried out in a large hospital located in Minas Gerais, Brazil, which provides care to patients from the private network and the public system (Sistema Único de Saúde). The hospital has 340 beds distributed in wards, apartments, and operating rooms, and has 60 adult intensive care beds, with 20 for cardiovascular patients and 40 for general ICU.

Inclusion criteria were patients aged $\geq 18$ years; without injury presence at admission; admission to the ICU for at least 48 hours; having been submitted to risk assessment for pressure injury by the Braden Scale upon admission; and classified as at-risk with a score between 6 and 18. Deaths were considered losses.

The surveyed variables included age, gender, reason which led to hospitalization, associated diseases, breathing mode, type of intake, risk of pressure injury according to the Braden scale (low risk=15 to 18 ; moderate risk=13 to 14 ; risk high $=10$ to 12 ; very high risk $=6$ to 9$)^{14}$, urinary and fecal incontinence, presence of medical devices, presence of medical adhesives, serum albumin $(3.5 \mathrm{~g} / \mathrm{dL}$ to $5.7 \mathrm{~g} / \mathrm{dL}$ ) and serum hemoglobin (reference - woman: $12 \mathrm{~g} / \mathrm{dL}$ to $16 \mathrm{~g} / \mathrm{dL}$; and man: $14 \mathrm{~g} / \mathrm{dL}$ to $18 \mathrm{~g} / \mathrm{dL}$ ). Variables related to injuries acquired during hospitalization were also considered: type of injury, quantity, location and the pressure injury stage.

The data were extracted from the electronic medical record (MVPEP ${ }^{\circledR}$ ) in 2018. The sample was composed by convenience and initially consisted of 400 medical records of patients who were admitted to the ICU in September, October and November 2017. However, a total of 275 patients were excluded for not meeting the inclusion criteria, resulting in 125 patients who composed the final study sample.

After performing data collection and construction of a database in the Microsoft Office Excel ${ }^{\circledR}$ version 2007 program, the analyzes were performed in $\mathrm{R}$ version 3.6.0 and Epilnfo version 7.2 software programs. The significance level was set at $5 \%$. Data were analyzed using descriptive statistics and categorical variables presented by frequency and percentages.

The Yates' chi-squared test was performed to compare the dichotomous categorical variables, and Fisher's exact test was used when there was at least one expected frequency less than 5. Furthermore, the Mann-Whitney test was used since the normality assumption was not met when comparing the age of the patients and injury appearance. Odds Ratio (OR) and logistic regression were also performed to build the models. It is noteworthy that the ratio between the number of patients with a specific injury and the number of patients at risk for that etiology was considered in calculating the incidence of skin injuries.

The study was approved by the Research Ethics Committee of the Federal University of Minas Gerais and the institution where the study was conducted, respecting the rules of the National Health Council of Brazil. Informed consent was not obtained because the study was retrospective, used a secondary data source (electronic medical record), and the researcher had no contact with patients or family members. All analyzed data were collected from the medical records as part of the routine diagnosis and treatment. 


\section{RESULTS}

A total of 125 patients comprised the study sample and were allocated into two groups: those who did not develop skin injuries during ICU hospitalization $(n=90)$ and those who developed some type of skin injury $(n=35)$. The overall injury incidence was $28 \%(n=35)$, and considering each etiology, $36.3 \%(n=8)$ were incontinence-associated dermatitis, and $19.2 \%(n=24)$ pressure injury, with $16.0 \%$ $(n=20)$ being in bony prominences and $8.0 \%(n=10)$ related to medical devices, $7.2 \%(n=9)$ skin tears, and $0.8 \%(n=1)$ medical-adhesive-related skin injuries.

The median age in the group without injury was 69 years with a standard deviation of 18.7 , while it was 69.1 years with a standard deviation of 18.3 in the group with injury ( $p$-value $=0.101$, MannWhitney test). Female patients predominated in both groups, and the main reasons for hospitalization were neoplasms and impaired respiratory system. Univariate logistic regression analyzes were performed to verify the significance of the variables that were associated with the appearance of skin injuries, as well as an Odds Ratio evaluation to verify the chance of a certain variable influencing the occurrence of injuries (Table 1).

An analysis of the multivariate model of logistic regression was subsequently performed, in which all covariates which were significant in the univariate analysis were inserted, namely: breathing mode, type of nutrition, urinary incontinence, and fecal incontinence. A significance level of $p \leq 0.25$ was used for inclusion in the multivariate model. The final models presented only one independent variable, however, the analysis of the multivariate model allowed to identify which were the categories with statistical significance ( $p$-value $\leq 0.05)$ for the appearance of injuries. These are highlighted in Table 1 and identified by the $\mathbb{1}$ symbol.

Thus, regarding the breathing mode, it was observed in the logistic regression analysis that patients on mechanical ventilation $(p=0.001)$ are 16.5 times more likely to have the appearance of some type of skin injury when compared to patients in an ambient air environment $(95 \% \mathrm{Cl} 3.2$ to 83.5). There was no statistically significant difference between those with oxygen through nasal catheter and non-invasive mechanical ventilation ( $p>0.05)$.

Regarding the type of nutrition, patients with enteral feeding $(p<0.001)$ were 20.7 times more likely to present injuries than patients with oral feeding ( $95 \%$ Cl 7.9 to 59.7). There was no statistically significant difference between those with parenteral nutrition and suspended diet $(p>0.05)$.

Patients with indwelling urinary catheters and in diapers $(p=0.004)$ for urinary incontinence were 4.1 times more likely to manifest injuries when compared to continent patients in diapers (95\% $\mathrm{Cl}: 1.5$ to 11.1$)$. Furthermore, patients with urinary diversion in diapers $(p=0.004)$ were 13.7 times more likely to present injuries in relation to continent patients ( $95 \% \mathrm{Cl}: 1.0$ to 174.8$)$. There was no statistically significant difference between urinary incontinent patients in diapers compared to continent patients $(p>0.05)$.

With regard to fecal incontinence, incontinent patients wearing diapers $(p=0.049)$ were approximately 3.0 times more likely to have skin injuries than continent patients (95\% $\mathrm{Cl}: 1.1$ to 8.6$)$. 
Table 1 - Sociodemographic profile and clinical conditions of patients. Belo Horizonte, MG, Brazil, 2019. $(n=125)$

\begin{tabular}{|c|c|c|c|c|c|c|c|}
\hline \multirow{3}{*}{ Characteristics } & \multicolumn{4}{|c|}{ Emergence of skin injury } & \multirow{3}{*}{ P-value } & \multirow{3}{*}{ OR } & \multirow{3}{*}{$\mathrm{Cl}_{95 \%}$} \\
\hline & \multicolumn{2}{|c|}{ Yes } & \multicolumn{2}{|c|}{ No } & & & \\
\hline & $\mathbf{n}$ & $\%$ & $\mathbf{n}$ & $\%$ & & & \\
\hline Gender & & & & & $0.981^{\ddagger}$ & & \\
\hline Female & 21 & 60.0 & 52 & 57.8 & & 1.1 & 0.49 to 2.43 \\
\hline Male & 14 & 40.0 & 38 & 42.2 & & 1.0 & \\
\hline Breathing mode & & & & & $<0.001^{\S}$ & & \\
\hline Ambient air & 2 & 5.7 & 18 & 20.0 & & 1.0 & \\
\hline Catheter oxygen nasal therapy & 9 & 25.7 & 58 & 64.4 & & 1.4 & 0.27 to 7.06 \\
\hline $\begin{array}{l}\text { Mechanical ventilation } \\
(\text { OOT/TCT* })^{\pi}\end{array}$ & 22 & 62.9 & 12 & 13.3 & & 16.5 & 3.2 to 83.5 \\
\hline Non-invasive mechanical ventilation & 2 & 5.7 & 2 & 2.2 & & 9.0 & 0.78 to 103.7 \\
\hline Type of nutrition & & & & & $<0.001^{\S}$ & & \\
\hline Oral & 6 & 17.1 & 67 & 74.4 & & 1.0 & \\
\hline Enteral" & 26 & 74.3 & 14 & 15.6 & & 20.7 & 7.9 to 59.7 \\
\hline Parenteral & 2 & 5.7 & 4 & 4.4 & & 5.6 & 0.8 to 37.1 \\
\hline Suspended & 1 & 2.9 & 5 & 5.6 & & 2.2 & 0.2 to 22.4 \\
\hline Urinary incontinence & & & & & $0.003^{\S}$ & & \\
\hline Continent with diaper & 6 & 17.1 & 41 & 44.4 & & 1.0 & \\
\hline $\mathrm{IDC}^{\dagger}$ and diaper ${ }^{\pi}$ & 27 & 77.1 & 44 & 48.85 & & 4.1 & 1.5 to 11.1 \\
\hline Incontinent with diaper & 0 & 0.0 & 4 & 4.4 & & $\|$ & $\|$ \\
\hline Urinary diversion and diaper ${ }^{\pi}$ & 2 & 5.7 & 1 & 1.1 & & 13.7 & 1.0 to 174.8 \\
\hline Fecal incontinence & & & & & $0.049^{\ddagger}$ & & \\
\hline Yes & 9 & 25.7 & 9 & 10.0 & & 3.1 & 1.1 to 8.6 \\
\hline No & 26 & 74.3 & 81 & 90.0 & & 1.0 & \\
\hline Serum albumin & & & & & $0.269^{\ddagger}$ & & \\
\hline$<3.5 \mathrm{~g} / \mathrm{dL}$ & 30 & 88.2 & 57 & 77.0 & & 1.0 & \\
\hline 3.5 to $5.7 \mathrm{~g} / \mathrm{dL}$ & 4 & 11.8 & 17 & 23.0 & & 0.5 & 0.1 to 1.5 \\
\hline No information & 1 & - & 16 & - & & & \\
\hline
\end{tabular}

${ }^{*}$ TCT: tracheostomy, OTT: orotracheal tube; † IDC: indwelling urinary catheter; $\ddagger$ Chi-squared test with Yates correction; \$Fisher's Exact Test; "test not performed; "Logistic Regression.

There were 21 female patients in the group of patients who developed some type of injury, of which $19(90.4 \%)$ had serum hemoglobin levels $<12.0 \mathrm{~g} / \mathrm{dL}$, while $2(9.6 \%)$ had serum hemoglobin with values between 12.0 and $16.0 \mathrm{~g} / \mathrm{dL}$. All male patients $(n=14)$ in this group had serum hemoglobin levels $<14.0 \mathrm{~g} / \mathrm{dL}$. A total of $52(57.8 \%)$ women were in the group of patients who did not develop skin injuries, of whom $32(61.5 \%)$ had serum hemoglobin levels $<12.0 \mathrm{~g} / \mathrm{dL}$, and $20(38.5 \%)$ had hemoglobin between 12.0 and $16.0 \mathrm{~g} / \mathrm{dL}$. Of the 38 male patients in this group, $34(89.5 \%)$ had hemoglobin values $<14.0 \mathrm{~g} / \mathrm{dL}$, and $4(10.5 \%)$ had values between 14.0 and $18.0 \mathrm{~g} / \mathrm{dL}$.

The main associated diseases identified in patients who developed some type of skin injury were systemic arterial hypertension (54.2\%), cancer (34.6\%) and diabetes mellitus (31.4\%). No association was observed between the appearance of injuries and the presence of an associated disease (Table 2). 
Table 2 - List of associated diseases of patients. Belo Horizonte, MG, Brazil, 2019. $(n=125)$

\begin{tabular}{|c|c|c|c|c|c|}
\hline \multirow{3}{*}{ Diseases } & \multicolumn{4}{|c|}{ Emergence of skin injury } & \multirow{3}{*}{ P-value } \\
\hline & \multicolumn{2}{|c|}{ Yes } & \multicolumn{2}{|c|}{ No } & \\
\hline & $\mathrm{n}$ & $\%$ & $\mathbf{n}$ & $\%$ & \\
\hline \multicolumn{6}{|l|}{ Hypertension } \\
\hline Yes & 19 & 54.2 & 56 & 62.2 & $0.542^{*}$ \\
\hline No & 16 & 45.7 & 34 & 37.8 & \\
\hline \multicolumn{6}{|c|}{ Diabetes Mellitus } \\
\hline Yes & 11 & 31.4 & 36 & 40.0 & $0.495^{*}$ \\
\hline No & 24 & 68.6 & 54 & 60.0 & \\
\hline \multicolumn{6}{|l|}{ Cancer } \\
\hline Yes & 12 & 34.3 & 15 & 16.7 & $0.056^{*}$ \\
\hline No & 23 & 65.7 & 75 & 83.3 & \\
\hline \multicolumn{6}{|l|}{ Depression } \\
\hline Yes & 1 & 2.9 & 3 & 3.3 & $1.000^{\dagger}$ \\
\hline No & 34 & 97.1 & 87 & 96.7 & \\
\hline \multicolumn{6}{|c|}{ Chronic obstructive pulmonary disease } \\
\hline Yes & 4 & 11.4 & 3 & 3.3 & \\
\hline No & 31 & 88.6 & 87 & 96.7 & $1.000^{\dagger}$ \\
\hline \multicolumn{6}{|c|}{ Hypothyroidism } \\
\hline Yes & 6 & 17.1 & 13 & 14.4 & $0.095^{\dagger}$ \\
\hline No & 29 & 82.9 & 77 & 85.6 & \\
\hline \multicolumn{6}{|l|}{ Dyslipidemia } \\
\hline Yes & 6 & 17.1 & 18 & 20.0 & $0.911^{*}$ \\
\hline No & 29 & 82.9 & 72 & 80.0 & \\
\hline \multicolumn{6}{|c|}{ Peripheral obstructive arterial disease } \\
\hline Yes & 3 & 8.6 & 6 & 6.7 & $0.709^{\dagger}$ \\
\hline No & 32 & 91.4 & 84 & 93.3 & \\
\hline \multicolumn{6}{|c|}{ Chronic renal failure } \\
\hline Yes & 6 & 17.1 & 21 & 23.3 & $0.608^{*}$ \\
\hline No & 29 & 82.9 & 69 & 76.7 & \\
\hline \multicolumn{6}{|l|}{ Alzheimer's } \\
\hline Yes & 1 & 2.9 & 4 & 4.4 & $1.000^{\dagger}$ \\
\hline No & 34 & 97.1 & 86 & 95.6 & \\
\hline \multicolumn{6}{|l|}{ Obesity } \\
\hline Yes & 5 & 14.3 & 8 & 8.9 & $0.514^{\dagger}$ \\
\hline No & 30 & 85.7 & 82 & 91.9 & \\
\hline \multicolumn{6}{|l|}{ Heart failure } \\
\hline Yes & 5 & 14.3 & 3 & 3.3 & $0.384^{\dagger}$ \\
\hline No & 30 & 85.7 & 87 & 96.7 & \\
\hline \multicolumn{6}{|c|}{ Alcohol consumption } \\
\hline Yes & 3 & 8.5 & 3 & 3.3 & $0.087^{\dagger}$ \\
\hline No & 29 & 83.0 & 85 & 94.5 & \\
\hline Abstinence & 3 & 8.5 & 2 & 2.2 & \\
\hline \multicolumn{6}{|l|}{ Smoking } \\
\hline Yes & 3 & 8.5 & 3 & 3.3 & $0.178^{\dagger}$ \\
\hline No & 26 & 74.3 & 78 & 86.7 & \\
\hline Abstinence & 6 & 17.2 & 9 & 10.0 & \\
\hline
\end{tabular}

"Chi-squared test with Yates correction; ${ }^{\dagger}$ Fisher's Exact Test 
As the studied ICU protocol, all patients admitted to the sector are assessed for the risk of developing pressure injury using the Braden scale. Therefore, although this scale is not validated to assess the risk of developing skin injuries of other etiologies (such as incontinence-associated dermatitis, skin tears or medical device-related pressure injury or medical-adhesive-related skin injury), all patients who developed some type of injury were classified as at-risk by the Braden scale (Figure 1).

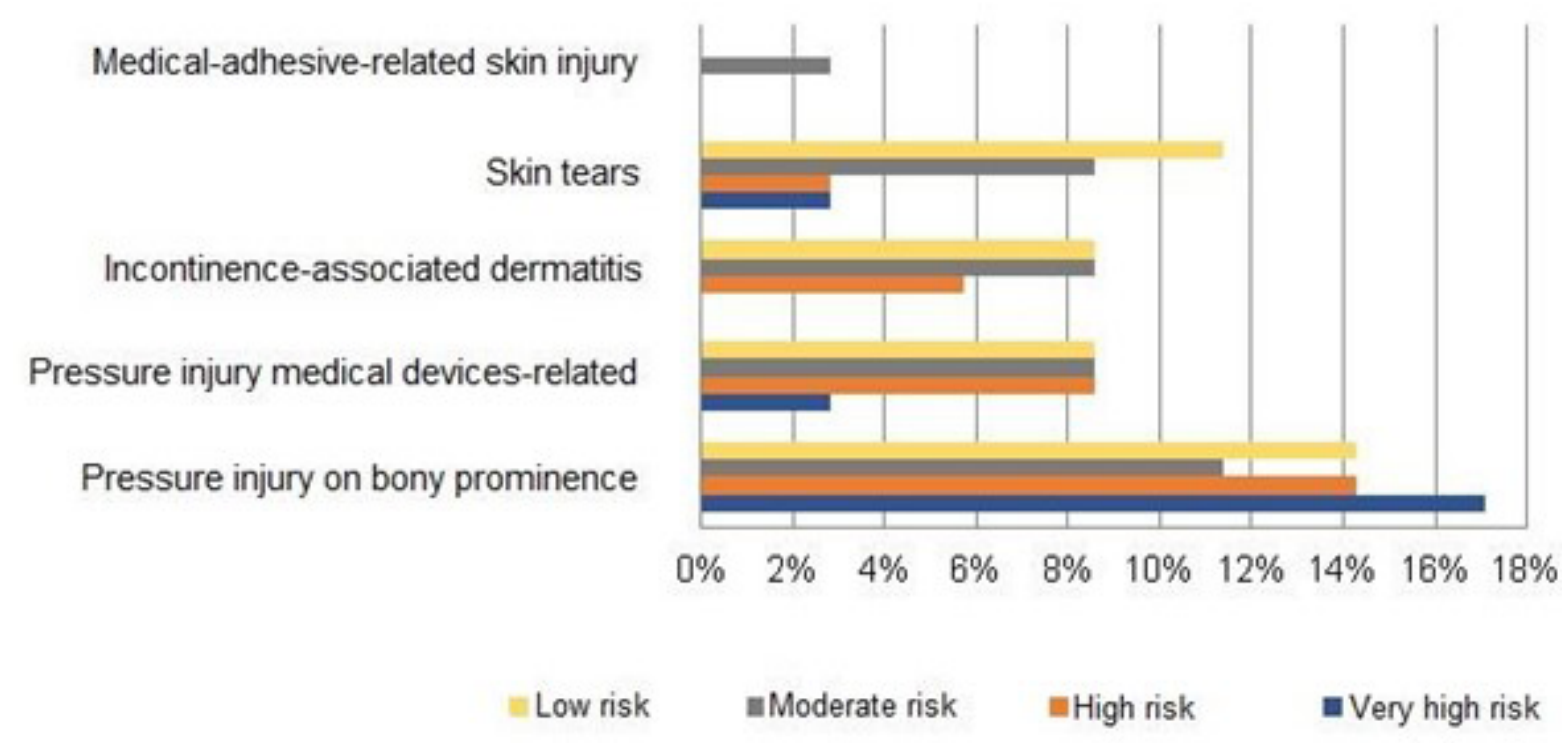

Figure 1 - Risk score using the Braden scale of patients who developed a skin injury. Belo Horizonte, MG, Brazil, 2019. $(n=35)$

Of the total number of patients in the group with some skin injury $(n=35), 42.8 \%(n=15)$ developed more than one injury during hospitalization, including different injuries or the same etiology (Figure 2), totaling 61 injuries.

The only medical-adhesive-related skin injury occurred in the thigh region and was caused by the use of medical adhesive tape. The 11 friction injuries occurred in $63.6 \%(n=7)$ of the cases in the upper limbs, $18.2 \%(n=2)$ in the lower limbs and $18.2 \%(n=2)$ in the auricular pavilion.

The 8 occurrences of incontinence-associated dermatitis were in the perianal region in $37.5 \%$ $(n=3)$ of the cases, $37.5 \%(n=3)$ in the gluteal, inguinal and groin regions, and $25.0 \%(n=2)$ restricted to the intergluteal region.

Pressure injuries in bony prominences and related to medical devices totaled 41 occurrences. Of the 11 medical device-related pressure injuries, $72.7 \%(n=8)$ were caused by the orotracheal tube, $18.2 \%(n=2)$ by the indwelling urinary catheter, and $9.1 \%(n=1)$ by a nasal catheter.

Of the 30 injuries in bony prominences, $46.7 \%(n=14)$ were classified as stage 1 , and $53.3 \%$ $(n=16)$ as stage $2 ; 36.7 \%(n=11)$ were in the sacral region, $23.3 \%(n=7)$ in the trochanteric region, $20.0 \%(n=6)$ on the heels, $13.3 \%(n=4)$ in the malleoli and $6.7 \%(n=2)$ on the scapula and elbow. 


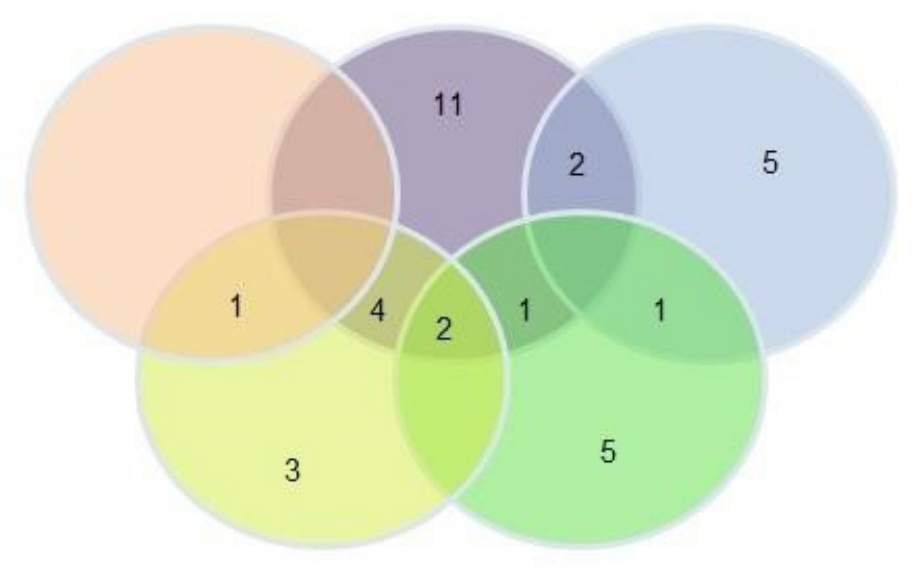

\footnotetext{
- Medical-adhesive-related skin injury

- Pressure injury in bony prominence

- Incontinence-associated dermatitis

- Skin tears

Pressure injury medical devic es-related
}

*Some patients developed more than one skin injury.

Figure 2 - List of patients who developed skin injuries by etiology. ${ }^{*}$ Belo Horizonte, MG, Brazil, 2019. ( $\left.n=35\right)$

The hospitalization period ranged from 3 to 17 days in the group without injury, with an average of 5.1 days and standard deviation of 2.9 , while it was from 3 to 45 days in the group with injury, with an average of 12.5 days and standard deviation of 10.5 (Figure 3 ).

The time for the injury appearance was on average 10.1 days, and the period between the appearance of the first and the second injury in patients who had more than one injury was on average 4.5 days.

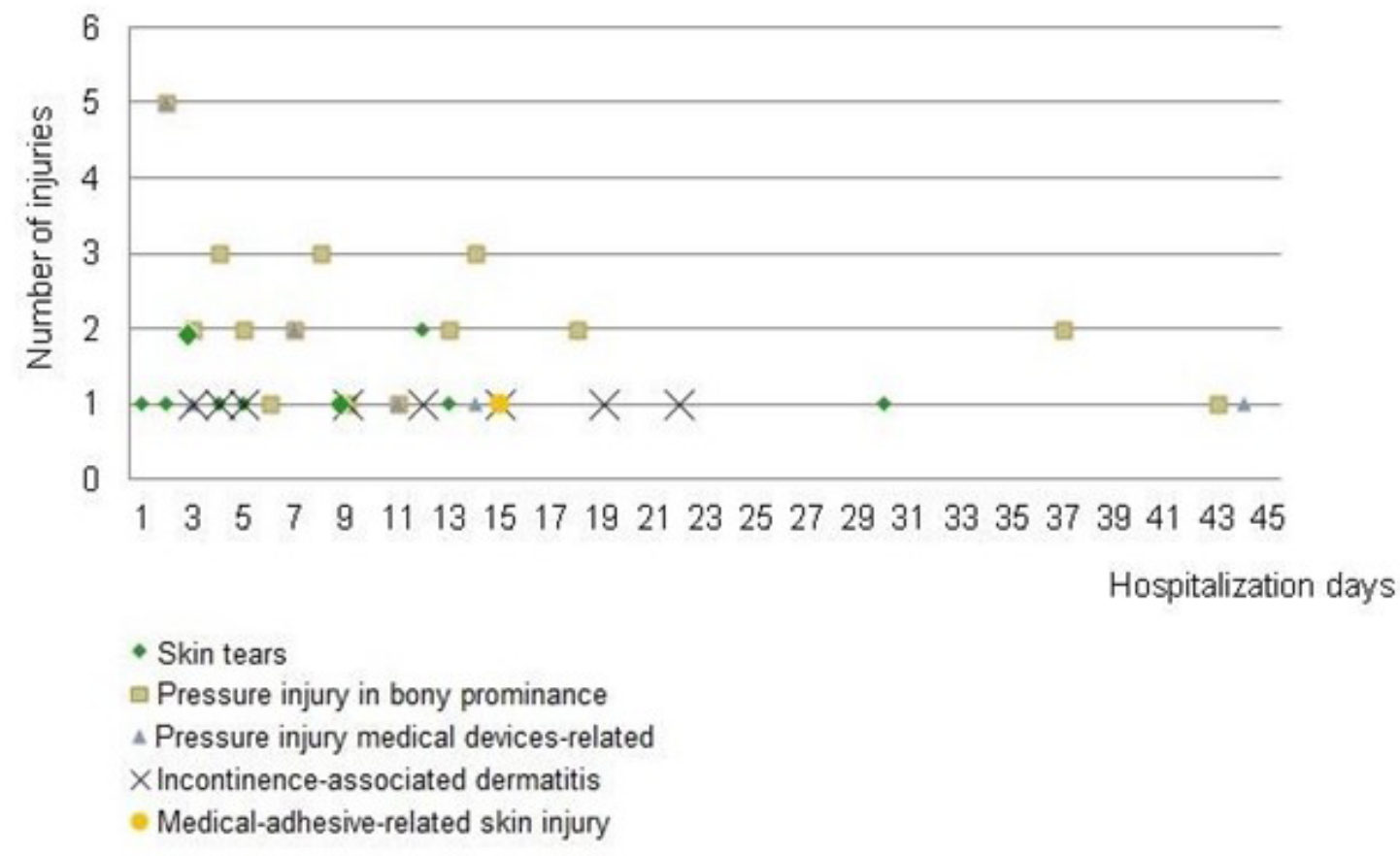

Figure 3 -Emergence of injuries according to etiology, depending on the hospitalization period. Belo Horizonte, MG, Brazil, 2019. $(n=61)$ 


\section{DISCUSSION}

Nurses deal with care complexities for at-risk patients and with injuries of different etiologies, taking precautions to ensure that new injuries do not develop. This study provided detailed information on the incidence of injuries, risk factors, patient characteristics and nursing care interventions in a Brazilian ICU.

The injury incidence in the ICU including several etiologies was $28 \%$; however, this data has not been compared with the results of studies carried out in the intensive care settings in Brazil and in other countries, since the publications present an injury incidence of only one etiology, with the most common being pressure injury.

Professionals commonly consider injuries resulting from pressure and which affect a bony prominence as an adverse event. The remaining injuries are ignored, and this fact interferes with the true number of records and adopting effective measures for their prevention.

In a systematic review involving 22 epidemiological studies, 10 reported a cumulative pressure injury incidence of $10.0 \%$ to $25.9 \%$, regardless of the stage. The cumulative incidence $(95 \% \mathrm{Cl})$ in studies which used skin inspection to identify this type of injury was $9.4 \%$ to $27.5 \%$. The cumulative incidence $(95 \% \mathrm{Cl})$ in studies assessed as low risk of bias was $6.6 \%$ to $36.8 \%$. Furthermore, the cumulative incidence $(95 \% \mathrm{Cl})$ when the stage 1 pressure injury was excluded was $0.0-23.8 \%{ }^{15}$.

These data support the possibility that nurses confuse stage 1 and 2 pressure injuries with injuries of other etiologies, for example with incontinence-associated dermatitis, skin tears and medicaladhesive-related skin injury. In addition, they corroborate the possibility of inducing underreporting of the occurrence of these injuries when they are not considered important by institutional culture, culminating in changing the incidence value when it involves injuries of any etiology.

In this study, 11 of the 41 pressure injuries were related to medical devices and were caused by tubes (orotracheal) and catheters (indwelling and nasal vesical). Patients using a urinary catheter and diaper were 4.1 times more likely to develop some type of skin injury when compared to those without a urinary catheter. Moreover, patients on mechanical ventilation were 16.5 times more likely to develop injuries than patients only on ambient air. Such data may be related to the appearance of medical device-related pressure injury due to the prolonged fixation of tubes and catheters.

A systematic review with 29 studies involving data from 126,150 patients had an estimated medical device-related pressure injury incidence of $12 \%$ (95\% Cl 8-18). The commonly identified medical devices associated with the risk of developing pressure injuries included breathing devices, cervical collars, tubes, splints and intravenous catheters ${ }^{16}$.

Medical device-related pressure injuries are among the main indicators of patient safety and nursing care quality in health services, however this relevance is not yet translated into abundant scientific production. Such injuries characterize an important problem, especially as they affect the well-being of patients and increase the costs of care for both patients and providers ${ }^{16}$.

It is noteworthy that the use of medical devices is also not included in the risk assessment scales for pressure injuries, such as the Braden Scale ${ }^{14}$, which is the most widely used in Brazil for this purpose ${ }^{17}$. This fact reinforces the need for more research which promotes strategies to improve risk assessment and record these injuries.

All pressure injuries that occurred in bony prominences in this study were classified as stage 1 or $2(46.7 \%$ and $53.3 \%)$, and were frequently in the sacral $(36.7 \%)$ and trochanteric $(23.3 \%)$ regions. This is similar to data from studies in other countries ${ }^{10-11}$ and supported by the fact that a critical patient often has changes in decubitus due to clinical instability or the use of multiple devices such as the orotracheal tube. 
Pressure injuries from stages 1 and 2 demand more attention regarding preventive measures to avoid worsening the condition, since injuries in the early stages are more common and can be easier to treat and prevent. Healthcare providers must not only treat a patient's injuries, they must also take measures to prevent the development of new injuries; a fact identified in this research, considering that $42.8 \%(n=15)$ of patients developed more than one injury during ICU hospitalization.

The incidence of incontinence-associated dermatitis found herein is considered high when compared to international ${ }^{7}$ and Brazilian data ${ }^{5}$. The incidence of skin tears was low in relation to the literature which presents records between $2.2 \%$ and $92.0 \%{ }^{18}$, constituting a fact that in this study may be associated with underreporting the occurrence of these injuries.

Regarding the presence of faecal and urinary incontinence, it was observed that the majority of patients used an indwelling urinary catheter, regardless of having urinary incontinence. However, those patients who used diapers unnecessarily because they were using a delayed urinary catheter or had a urinary diversion were associated with the appearance of some skin injury $(p=0.004)$. Such a fact may be related to the alteration of the skin's microclimate, especially due to the increase in temperature caused by the presence of the diaper. In this case, the protective barrier provided by the skin is compromised.

All hospitalized patients used diapers during hospitalization and those who presented incontinence-associated dermatitis had fecal-type incontinence. It is noteworthy that the prolonged use of diapers alters the microclimate because it predisposes the patient to increased temperature and humidity in the sacral region, leading to the occurrence of dermatitis ${ }^{2,6}$ and pressure injuries.

Other associated factors are the use of multiple bedding layers on the bed, restricted mobility of patients and prolonged hospital stay ${ }^{7}$. Therefore, the existence of institutional protocols for preventing skin injuries which contemplate changing positions; a standard routine of changing diapers, including intimate hygiene; repositioning and fixing the devices; skin care, such as hydration and protection; in addition to using cushions for positioning are recommended. It is noteworthy that the protocol in the institution where the study was conducted contemplates these items, however there was no record in the medical record regarding the performance of all of them.

Most patients who developed pressure injury in a bony prominence had a very high risk (6 to 9) using the Braden scale, and occasionally developed more than one type of injury. In a study carried out in Norway involving 4 hospitals, it was found that $19.4 \%$ of pressure injuries occurred in people with a Braden score $<17,{ }^{11}$ and in a study carried out in India, $31.8 \%$ of patients who developed pressure injuries had a Braden score $<16^{19}$.

Regarding the health profile, most of the patients in the group with injury were older adults, and invasive mechanical ventilation (TCT/OTT) $(p=0.001)$ and enteral nutrition $(p<0.001)$ were among the factors associated with the development of some type of injury according to multivariate logistic regression. Although mechanical ventilation represents a necessary oxygenation source in critically ill patients, it can be a predisposing factor for developing pressure injuries in these patients in both bony prominences and related to medical devices. An orotracheal tube is one of the main devices cited in the literature as causing medical device-related pressure injury, mainly on the lips and ears due to prolonged fixation ${ }^{4,16}$. In addition, the use of the respirator often imposes a position to the critical patient which favors developing a pressure injury in the sacral region.

Enteral nutrition was a predictor for development of some type of injury $(p<0.001)$. It is noteworthy that this is not an isolated factor, considering that patients using an enteral diet had impaired nutritional status. The result obtained may be associated with other variables related to malnutrition, for example laboratory indexes of albumin, since this protein is of great importance in the wound healing process, increasing angiogenesis, synthesis and collagen remodeling ${ }^{1-2}$. 
Nutritional status is an extremely important factor in preventing skin damage, especially pressure injury. Nutritional deficit directly impacts tissue tolerance, mechanical skin properties, tissue morphology and physiological properties such as repair and thermal properties ${ }^{2}$.

Another important fact was the appearance of injuries in the first days of hospitalization, especially pressure injuries in bony prominences, which occurred in the first three days of hospitalization.

The length of hospital stay can be associated with the emergence of pressure injuries, as the longer the hospital stay, the greater the chance of its occurrence ${ }^{20}$. However, most of these injuries occur in the first hospitalization days in at-risk patients ${ }^{21}$. Considering that these and other injuries are preventable, it is fundamentally important to establish and implement prevention and patient safety measures by the care team. The patient's safety culture can be an influencing factor in the occurrence of the injury during the hospitalization period ${ }^{11}$.

Measures such as humidity management, position changes according to the individual need of each patient, use of support surfaces for pressure redistribution, repositioning the fixation of devices, nutritional and risk assessment are some of the recommendations aimed at preventing injuries ${ }^{2}$. Therefore, these measures must be systematized, implemented and culturally developed by the entire nursing team as part of care safety management and quality effectiveness.

This research has some characteristic limitations of a study which uses secondary sources to obtain data, especially regarding its precision, since many data are often missing, underreported or incompletely registered. Such an eventuality does not enable obtaining information about certain variables necessary for analysis and possible inferences or statistical associations.

Another limitation corresponds to the time period contemplated by the study, which may have made it impossible to increase the sample size between the two groups (with and without injury), which prevented the performance of certain statistical analyzes. This was a single center study and the injury incidence may vary between different health services.

Although data on skin injuries are recorded, there may be internal inconsistencies between nurses' reports. For example, incontinence-associated dermatitis may not be easily distinguished from pressure injuries in stages 1 and 2, and no differentiation between incontinence-associated dermatitis and pressure injuries appeared in the records.

The limitations found may direct an institution's professionals regarding the need for improvements in registering information about the care provided to patients, in addition to allowing methodological adjustments in case of reproducibility of the research in the form of new studies. On the other hand, the results presented herein can contribute to the literary scope and reflect the injury development scenario for managers and professionals who work in the care of critical patients.

\section{CONCLUSIONS}

Critical patients presented skin injuries of different etiologies and developed more than one injury during hospitalization. The study identified the overall incidence of injuries and by etiology. Most patients who developed pressure injuries were at very high risk due to the Braden risk score. An association of predisposing factors for skin injuries in patients has been demonstrated such as enteral nutrition, mechanical ventilation, fecal incontinence and the use of diapers with an indwelling urinary catheter or urinary diversion.

The higher incidence of incontinence-associated dermatitis and pressure injuries reflects the need for qualified care aimed at patient safety, which is essential for preventing these events, and must be carried out comprehensively and articulated in a multidisciplinary way. 


\section{REFERENCES}

1. Kanitakis J. Anatomy, histology and immunohistochemistry of normal human skin. Eur J Dermatol [Internet]. 2002 [cited 2019 Nov 30];12(4):390-401. Available from: https://jle.com/fr/revues/ ejd/e-docs/anatomy_histology_and_immunohistochemistry_of_normal_human_skin_100285/ article.phtml?tab=texte

2. European Pressure Ulcer Advisory Panel, National Pressure Injury Advisory Panel and Pan Pacific Pressure Injury Alliance. Prevention and Treatment of Pressure Ulcers/Injuries: Quick Reference Guide. Haesler E, ed. EPUAP/NPIAP/PPPIA [Internet]. 2019 [cited 2019 Nov 28]; Available from: https://internacionalguideline.com/guideline

3. Brasil. Agência Nacional de Vigilância Sanitária. Nota Técnica GVIMS/GGTES n03/2017: Práticas seguras para prevenção de Lesão por Pressão em serviços de saúde [Internet]. Brasília, DF(BR): Anvisa; 2017 [cited 2019 Dec 02]; Available from: http://portal.anvisa. gov.br/documents/33852/271855/Nota+T\%C3\%A9cnica+GVIMS-GGTES+n\%C2\%BA+032017/54ec39f6-84e0-4cdb-a241-31491ac6e03e

4. Hyun S, Moffatt-Bruce S, Cooper C, Hixon B, Kaewprag P. Prediction Model for Hospital-Acquired Pressure Ulcer Development: Retrospective Cohort Study. JMIR Med Inform [Internet]. 2019 [cited 2020 Feb 03];7(3):e13785. Available from: https://doi.org/10.2196/13785

5. Chianca TCM, Gonçales PC, Salgado PO, Machado BO, Amorim GL, Alcoforado CLGC. Incontinence-associated dermatitis: a cohort study in critically ill patients. Rev Gaúcha Enferm [Internet]. 2016 [cited 2020 Jan 31];37(Spe):e68075. Available from: https://doi.org/10.1590/19831447.2016.esp.68075

6. Gray M, Giuliano KK. Incontinence-associated dermatitis, characteristics and relationship to pressure injury: a multisite epidemiologic analysis. JWOCN [Internet]. 2018 [cited 2019 Dec 04]; 45(1):63-7. Available from: https://doi.org/10.1097/WON.0000000000000390

7. Kayser SA, Phipps L, VanGilder CA, Lachenbruch C. Examining Prevalence and Risk Factors of Incontinence-Associated Dermatitis Using the International Pressure Ulcer Prevalence Survey. JWOCN. [Internet]. 2019 [cited 2020 Jan 15];46(4):285. Available from: https://doi.org/10.1097/ WON.0000000000000548

8. Strazzieri-Pulido K, Peres G, Campanili T, Santos V. Skin tear prevalence and associated factors: a systematic review. Rev Esc Enferm USP [Internet]. 2015 [cited 2020 Jan 31];49(4):668-74. Available from: https://doi.org/10.1590/S0080-623420150000400019

9. Ousey K, Wasek S. Clinician perspectives on medical adhesive-related skin injuries. Wounds UK [Internet]. 2019 [cited 2020 Feb 09];12(4):42-6. Available from: https://eprints.hud.ac.uk/id/ eprint/30112

10. Biçer EK, Güçlüel Y, Türker M, Kepiçoğlu NA, Şekerci YG, Say A. Pressure ulcer prevalence, incidence, risk, clinical features, and outcomes among patients in a Turkish hospital: a crosssectional, retrospective study. Wound Manag Prev [Internet]. 2019 [cited 2020 Feb 09];65(2):20-8. Available from: https://www.ncbi.nlm.nih.gov/pubmed/30730302

11. Bredesen IM, Bjøro K, Gunningberg L, Hofoss D. Patient and organizational variables associated with pressure ulcer prevalence in hospital settings: a multilevel analysis. BMJ Open [Internet]. 2015 [cited 2019 Dec 13];5:e007584. Available from: https://doi.org/10.1136/bmjopen-2015-007584

12. Brasil. Agência Nacional de Vigilância Sanitária. Núcleos de Segurança do Paciente. Relatórios Eventos Adversos dos Estados [Internet]. Brasília, DF(BR): Anvisa; 2019 [cited 2019 Dec 01]. Available from: http://portal.anvisa.gov.br/nucleos-de-seguranca-do-paciente

13. Hernández-Valles JH, Moreno-Monsiváis MG, Interial-Guzmán MG, Vázquez-Arreola L. Nursing care missed in patients at risk of or having pressure ulcers. Rev Latino-Am Enfermagem [Internet]. 2016 [cited 2020 Feb 11];24:e2817. Available from: https://doi.org/10.1590/1518-8345.1462.2817 
14. Bergstrom N, Braden BJ, Laguzza A, Holman V. The Braden scale for predicting pressure sore risk. Nurs Res.1987;36(4):205-10.

15. Chaboyer WP, Thalib L, Harbeck EL, Coyer FM, Blot S, Bull CF et al. Incidence and prevalence of pressure injuries in adult intensive care patients: a systematic review and meta-analysis. Crit Care Med [Internet]. 2018 [cited 2020 Feb 13];46(11):e1074-81. Available from: https://doi. org/10.1097/CCM.0000000000003366

16. Jackson D, Sarki AM, Betteridge R, Brooke J. Medical device-related pressure ulcers: a systematic review and meta-analysis. Int J Nurs Stud [Internet]. 2019 [cited 2020 Jan 10];92:109-20. Available from: https://doi.org/10.1016/j.ijnurstu.2019.02.006

17. Zimmermann GS, Cremasco MF, Zanei SSV, Takahashi SM, Cohrs CR, Whitaker IY. Pressure injury risk prediction in critical care patients: an integrative review. Texto Contexto Enferm [Internet]. 2018 [cited 2019 Dec 12];27(3):e3250017. Available from: https://doi.org/10.1590/010407072018003250017

18. Strazzieri-Pulido KC, Peres GRP, Campanili TCGF, Santos VLCG. Incidence of skin tears and risk factors: a systematic literature review. JWOCN. [Internet] 2017 [cited 2019 Dec 12];44(1):2933. Available from: https://doi.org/10.1097/WON.0000000000000288

19. Mehta C, George JV, Mehta Y, Wangmo N. Pressure ulcer and patient characteristics-a point prevalence study in a tertiary hospital of India based on the European Pressure Ulcer Advisory Panel minimum data set. J Tissue Viability [Internet]. 2015 [cited 2020 Jan 10];24(3):123-30. Available from: https://doi.org/10.1016/j.jtv.2015.04.001

20. Pachá HHP, Faria JIL, Oliveira KAD, Beccaria LM. Pressure Ulcer in Intensive Care Units: a case-control study. Rev Bras Enferm [Internet]. 2018 [cited 2020 Feb 01];71(6):3027-34. Available from: https://doi.org/10.1590/0034-7167-2017-0950

21. Rabeh SAN, Palfreyman S, Souza CBL, Bernardes RM, Caliri MHL. Cultural adaptation of the Pieper-Zulkowski pressure ulcer knowledge test for use in Brazil. Rev Bras Enferm [Internet]. 2018 [cited 2020 Feb 10];71(4):1977-84. Available from: https://doi.org/10.1590/0034-7167-2017-0029 


\section{NOTES}

\section{ORIGIN OF THE ARTICLE}

Extracted from the course conclusion work - Incidence of injury in general intensive care patients, presented to the Nursing Graduation Program at the Nursing School of the Federal University of Minas Gerais in 2019.

\section{CONTRIBUTION OF AUTHORITY}

Study desing: Monteiro DS, Borges EL, Spira JAO.

Data collection: Monteiro DS, Borges EL, Spira JAO.

Data analysis and interpretation: Monteiro DS, Borges EL, Spira JAO, Garcia TF, Matos SS.

Discussion of the results: Monteiro DS, Borges EL, Spira JAO, Garcia TF, Matos SS.

Writing and critical evaluation of the content: Monteiro DS, Borges EL, Spira JAO, Garcia TF, Matos SS.

Revision and approval of the final version: Monteiro DS, Borges EL, Spira JAO, Garcia TF, Matos SS.

\section{APPROVAL OF ETHICS COMMITTEE IN RESEARCH}

Approved by the Research Ethics Committee of the Federal University of Minas Gerais under the opinion number 2.294.382 / CAAE: 74427417.4.0000.5149 and by the Research Ethics Committee of the Felício Rocho Hospital under the opinion number 2.322.123 / CAAE: 74427417.4.3001.5125.

\section{CONFLICT OF INTEREST}

There is no conflict of interest.

\section{EDITORS}

Associated Editors: Selma Regina de Andrade, Gisele Cristina Manfrini, Natália Gonçalves, Monica Motta Lino.

Editor-in-chief: Roberta Costa.

\section{HISTORICAL}

Received: May 10, 2020.

Approved: November 03, 2020.

\section{CORRESPONDING AUTHOR}

Dandara Soares Monteiro

dandahmonteiro@hotmail.com 